\title{
AFRICAN ASSOCIATION OF INTERNATIONAL LAW ASSOCIATION AFRICAINE DE DROIT INTERNATIO- NAL
}

The AFRICAN ASSOCIATION OF INTERNATIONAL LAW was formed in 1986 at the Conference of African International Lawyers held in Lusaka, Zambia, from 2 to 5 April 1986. The African Association of International Law is an independent, non-governmental, non profit making and academic African association; it is continental wide and groups African international lawyers throughout the whole of Africa, be they in Governments, private, academic or in international organisations.

The Association is headed by Judge Taslim Olawale Elias (Nigeria), Judge and former President of the International Court of Justice, as the President and Judge Kéba Mbaye (Senegal), Judge of the International Court of Justice, as the First Vice-President, and has eight Vice-Presidents. Dr. Tunguru Huaraka (Namibia) human rights officer in the Centre for Human Rights of the United Nations is the Secretary-General of the Association. The inaugural Conference also elected by acclamation His Excellency Dr. K. D. Kaunda, President of the Republic of Zambia, the Patron of the Association, and Nelson Mandela the First Life Member, in recognition of their distinguished contributions to Africa.

The objects and purposes of the Association are: to forster the development and dissemination of African perspectives and practices of international law; to assist in the development of international law, recognizing the special needs of Africa; to promote the teaching of international law in Africa; and to encourage and co-ordinate research on international law mainly through the establishment of research and study groups on specific themes of relevance to Africa. In this regard it has established two research and study groups one dealing with refugee law and the other with humanitarian law in Africa. It is envisaged that now that the African Charter on Human and Peoples' Rights has entered into force, a research and study group on human rights, to provide a thoroughly researched framework for the African Commission on Human and Peoples' Rights, will be set up soon.

The Association will promote its objects and purposes mostly through its African Yearbook of International Law. The Editor-in-Chief of the African Yearbook of International Law is Judge Mohammed Bedjaoui (Algeria), Judge of the International Court of Justice. There are also two Executive Editors, one for French and the other for English, respectively namely: Prof. J. M. Bipoun Woum (Cameroon), Université de Yaoundé, Faculté de Droit et des Sciences Economiques, B. P. 1365, Yaoundé; Prof. Ebere Osieke (Nigeria), Dean, Faculty of Law, University of Jos, P. M. B. 2084, Jos, Nigeria. There are also 13 other members of the Editorial Board of the Yearbook. The Yearbook will be bi-lingual and the first volume is expected in the very near future. 
Apart from the 70 Founding Members, individuals are eligible for Ordinary Membership upon nomination by two members of regular standing. African law or international law societies may also be eligible for Institutional Membership.

The Secretariat of the Association is situated in Nairobi, Kenya, under the direction of Dr. B. A. Godana, Assistant Secretary-General/Treasurer of the Association. The address is as follows: Dr. B. A. Godana, Chairman, Department of Public Law, Faculty of Law, University of Nairobi, P. O. Box 30197, Nairobi, Kenya. The Secretary-General of the Association, Dr. Tunguru Huaraka, could be reached at 34, rue du Nant, 1207 Geneva, Switzerland.

The African Association of International Law hopes to establish in an African country a Documentation Centre and the Centre of Studies and Research in International Law. This is one of the major tasks of the Association. 